\title{
The sources of knowledge of two medieval Jewish commentators in nature issues: The case of gathering the musk (Song of Songs 5:1)
}

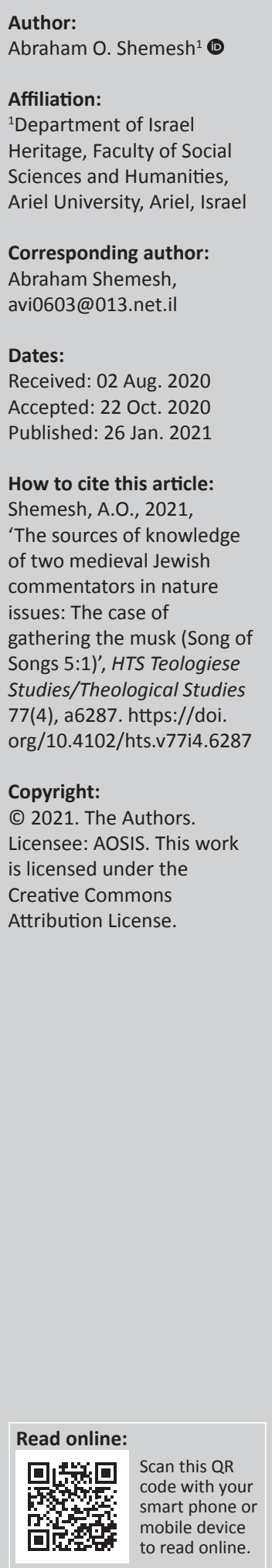

Musk, which is produced from the glands of several species of deer, was a well-known perfume throughout the Mediterranean Basin in the Middle Ages. The current article examines the meaning of the gathering operation of myrrh mentioned in Song of Songs 5:1, according to R. Joseph Ibn Aknin and Nahmanides. The two commentators argue that the phrase ariiti mori can be interpreted as the unique manner of gathering the perfume of the musk deer in its lands of origin in the Far East. They contend that harvesting the perfume refers to gathering the perfume that the deer spreads on the rocks naturally, which is a higher quality product. The two medieval rabbis were exposed to contemporary scholars or oral traditions on the way of gathering the musk. Ibn Aknin took the information from Arabic writings, such as of al-Sirāfī and al-Mas' ūdī and Ibn Juljul. With regard to Nahmanides, his source of information on gathering musk is not clear.

Contribution: This article contributes to the understanding of the issue of the sources of knowledge of scholars in medieval times and how the achieved information influenced their commentaries on the Biblical Text. The current study expounds the commentators' interpretations from a multidisplinary perspective, such as the medieval zoology and perfume industry.

Keywords: musk; musk deer; biblical myrrh; Song of Songs; Naḥmanides; Joseph Ibn Aknin; al-Sirāfī; al-Mas 'ūdī; medieval perfume industry; medieval commentators.

\section{Introduction}

Musk is an aromatic substance that over the generations has served as a perfume, spice and medicament. In ancient times, it was considered rare and to this day it has a place of honor in Far Eastern traditions. In the Middle Ages, musk was a well-known perfume throughout the Mediterranean region. Considerable documentation of its use appears in varied sources, such as books of geography, medicine, poetry and religion (On the uses of the musk according to the medieval literature, see Amar \& Lev 2017:157-161; Ingram 2012: 175; King 2017:8).

Musk was a tradable commodity in the ancient world and it was exported from its natural habitat in the Far East to markets throughout the Mediterranean region, such as Spain, Eretz Israel and Egypt (On the musk's trade routes in medieval, see Akasoy \& Yoeli-Tlalim 2007:217-240; King 2011:145-162, 2017:85-146). Documents of medieval merchants indicate that musk was marketed in several forms: (1) as a fluid in glass vessels; (2) musk pods in their organic form, which were removed from the body of the mammal and dried and (3) as a solid, in packets or bottles (Blau 2006:199; Goitein 1973:50, 1983:vol. IV, 454; Goitein \& Friedman 2013:115; Watt 1966: 786).

Musk is produced from the glands of several species of deer (the genus: Moschus) of which the most conspicuous is the Siberian musk deer (M. moschiferus), a cud-chewing mammal with no antlers that can be found in Siberia, Tibet and northern China. The male has long curved upper canines that protrude from the mouth. Under the belly, near the genitalia, is a pocket with special glands from which is secreted a soft viscous reddish-brown substance that has a sharp odour and bitter taste (Green 1987:307-319; Nowak 1991:vol II, 1364). The name 'musk' attached to this deer comes from 'muṣka', which means scrotum in Sanskrit (Shapira 1959a:153-161, 1959b:185-187).

\section{Purpose of the article}

This article discusses the meaning of the gathering operation mentioned in the verse 'I have gathered my myrrh with my spice' (Song of Songs 5:1), in light of the interpretation offered by two Jewish rabbis who lived in the 12th-13th centuries - Nahmanides and R. Joseph Ibn Aknin. 
Both rabbis suggest that the operation of 'gathering' the biblical myrrh can be interpreted as indicating the unique manner of gathering the perfume of the musk deer, one that was customary in their time.

The main purpose of this article is to follow the sources of the knowledge of the two rabbis concerning the gathering of the myrrh and discuss their interpretations in light of parallel testimonies by non-Jews scholars who too describe the gathering of musk.

\section{Identifying musk with the biblical myrrh by medieval sages}

Some medieval commentators identified the biblical myrrh (Ex 30:23; Song of Songs 4:12-14) with the perfume produced from musk deer. The first to propose such an identification was R. Sa'adya Gaon (Rasag, 882/892-942), who translates in his Arabic commentary on the bible: 'Mor-al-Miskh (in Arabic' (مسك)', that is musk (Sa'adya Gaon, Commentary of R. Sa'adya Gaon 1984:96).

R. Moses Ben Maimon (Maimonides, Spain and Egypt, 1138-1204) too identified myrrh with musk. When discussing the ingredients of the holy anointing oil that served to consecrate the priests and the temple vessels, he writes: 'Mor [=Musk] refers to the blood contained with a wild beast from India that is of universal renown which people everywhere use as a fragrance'. ${ }^{1}$ Maimonides describes the musk as 'blood that is solidified (tzarur) within the animal', and this wording derives from the biblical phrase 'a sachet of myrrh' (tzror hamor) in Song of Songs $1: 13$. This may be associated with the fact that the aromatic substance is located or 'enveloped' within a 4 centimetres (cm) $-7 \mathrm{~cm}$ long furry egg-shaped pocket (Maimonides 2002:hilkhot Klei ha-Mikdash, 1:3).

Several rabbis and modern researchers objected to the identification of biblical myrrh with musk. As an alternative, it was suggested that myrrh be identified with a perfume of vegetative origin, that is, the yellow-reddish crystalline resin produced from the trees of Commiphora abyssinica (Nahmanidas 1959:vol. I, 496; Veizer 1976, The short commentary on Ex 30:23, 197-198). ${ }^{2}$ The following are the main arguments against identifying myrrh with musk:

1. R. Abraham ben David, the Ravad (Provence 1125-1198) rejected the identification with musk, claiming that musk is the blood of an impure animal that is unfit for ritual activity in sacred sites (Ravad 2002, hilkhot Klei ha-Mikdash, 1:3). However, this argument is untenable, as the musk deer boasts the necessary signs

1.Maimonides 2002, hilkhot Klei ha-Mikdash, 1:3; $2: 4$; ibid, hilkhot berakhot $9: 1$ Maimonides 1970: Keritut 1:1. R. Joseph Karo (Spain and Land of Israel, 16th century) states that it is common by the people to identify the biblical myrrh as musk. See Karo 2002: hilkhot Klei ha-Mikdash, 1:3.

2.Compare to the words of R. Abraham Ben David in his criticism of Maimonides that Myrrh is 'kind of an herb or a tree that his scent is shedding' (Ravad 2002:hilkhot Klei ha-Mikdash, 1:3). On the resin of the myrrh and its characters, see Klei ha-Mikdash, 1:3). O
Löw 1924:vol. I, 305-312. that identify it as ritually clean - it has a split hoof and it chews its cud (according to Lv 11:3). The Ravad may have known that the male has two canines typical of carnivores and therefore thought that it is an impure animal.

2. R. Abraham Ibn Ezra (b. Toledo, c. 1090-1164) raises another difficulty (On Ibn Ezra, see Sela \& Freudenthal 2006:13-55). It is apparent from the verse in the Song of Songs 5:1 that myrrh originates from an aromatic plant, as in the Bible and in rabbinical literature 'gathering' (ariya) is interpreted as the act of harvesting agricultural produce, such as figs and grapes, rather than animal-based perfume (see, for example, Ps 80:3; Albeck 1952:Shevi'it 1:2).

In his short commentary which was compiled in Italy between 1142-1145, Ibn Ezra writes: "Mor dror" - the gaon [=Rasag] said: muskh [...] but it is [=the Mor] harvested and this is not true of the muskh' (Veizer 1976:The short commentary on Ex 30:23, 331). He as well addresses this difficulty in his long commentary, which was written in 1153 in the city of Daros or Rodus, probably the city Rouem in Normandy, northern France (Simon 2013:337-339):

It is written 'I have gathered my myrrh with my spice' [Song of Songs 5:1], that is, it is gathered, and those who bring it [=the musk] say that it is produced in the throat of the gazelle. [Ex 30:23] (Veizer 1976:The long commentary on Ex 30:23, 197-198).

Namely, the musk originates from the body of a 'gazelle' ( $t z v i)$ (see below) and the operation of harvesting or gathering is not relevant for substances produced from animals.

As claimed by modern researchers, the identification of the biblical myrrh with tree resin appears more logical, as attested by the various verses that link it to its habitat in the perfume gardens of tropical lands where exotic perfumeproducing trees grow (Song of Songs 4:14, 5:1; On the difficulties to identify the musk with the biblical myrrh, see Amar 2002:101-102).

\section{The description of musk gathering in Ibn Aknin's commentary}

The manner in which musk is gathered is described at length in the commentary written by R. Joseph Ben Judah Ibn Aknin (1150-1220) on the Song of Songs. Ibn Aknin was born in Barcelona, Catalonia. Being a converso, probably as a result of the Almohad persecutions, he (or perhaps his father) was compelled to leave his homeland and settled in the town of Fez in North Africa, and he remained there until his death. Ibn Aknin was a contemporary and friend of Maimonides, and he appears to have been a physician. He wrote dissertations on philosophy, medicine, biblical exegesis and Talmud, including a comprehensive Judeo-Arabic commentary on the Song of Songs (On the biography and works of Joseph ben Judah ibn Aknin, see Halkin 1944:27-37, 1963:93-111, 1964:11-12, 1971:501). 
In the opinion of R. Joseph Ibn Aknin, the myrrh in Song of Songs 5:1 should undoubtedly be identified with musk. His interpretation may have been intended to reinforce Maimonides' interpretive approach, as according to his writings they were not only friends but rather Ibn Aknin was an ardent admirer of Maimonides (Halkin 1964:431). Ibn Aknin's interpretation is devoted to proving that ariya means the unique operation of gathering the musk in the musk deer's natural habitat. His words were of course intended to refute the claim that the biblical term ariya is more appropriate for the harvesting of myrrh resin. He writes (Halkin 1964):

And ariti means 'I gathered'. Namely, I gathered and harvested. And some say that myrrh is a species of fragrant flowers because ariya is only used for plants that are gathered, and I say that it is musk, and this is unquestionable. And the word was borrowed for this purpose because it is taken from the gazelles as flowers are gathered from plants, since in the land of Tibet and China there are gazelles, and those in Tibet graze on aromatic and perfumed paths while those in China eat dry grass, and in these lands obstacles and snares are set for them and they are trapped. And they are usually shot with arrows and knocked down and their myrrh bladders are cut off them while the blood is in the belly and has not matured and it is fresh and not weaned [=fully developed] and it smells very bad and is put aside until the bad odor dissipates and the putrid smells are transformed into musk. And the best musk is that which matures in its vessels [=in its body parts] and is weaned in its navel and matured while still alive since nature pushes the blood substance to the navel and when the quality of the blood is ready and mature it causes the animal pain and itching. Then the gazelles flee to the rocks and stones that are hot from the sun and scratch themselves against them pleasurably and they open and spill onto these stones like bursting bubbles when their inner part becomes pus and they feel satisfied when it comes out and when emptied of the bladder's contents they are healed, and substances from the blood will push themselves into it [=and enter the bladder] as at first. Then the hunters go to them and head for their places of pasture and find the blood that has dried on those rocks by the sun and air and take it, and it is the choicest musk, and they put it in a bladder they took from fawns they captured, and this is the choicest musk, as written by the ancients concerning musk and we have conveyed this in their language. And if it is taken from the fawns [=gazelles] while hunting and it is not mature, then it is gathered from the stones, for this the word ariya was borrowed. (p. 245)

Ibn Aknin relates that musk is produced from deer found in Tibet and China, and he distinguishes between the two habitats - in Tibet, the deer graze on aromatic plants, whilst in China the deer feed on dry grass. In the ancient world, the Tibetan perfume was considered of the best quality (Amar \& Lev 2017:157). The outlook whereby the origins of the musk fragrance comes from aromatic plants eaten by the deer was articulated by Nahmmanides. In his Iggeret ha-Kodesh [The holy letter], he writes:

It is known that everything goes by the food, it affects the body. And research shows that the animal from which the

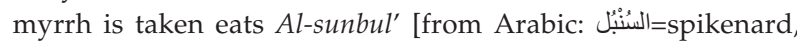
Nardostachys grandiflora=N. jatamansi]. (Nahmanides 1955:329. See also Nahmanides 1959:vol. I, 496)

Accordingly, it appears that the Tibetan myrrh is considered choicer by virtue of eating aromatic plants.
According to Ibn Aknin's description, musk was produced in two ways. The first is by capturing the musk deer with traps or by shooting arrows. After it was captured, the 'bladder' [=the pocket in which the secretion is accumulated], located under the belly near the genitalia, was cut off. However, this generated perfume that did not reach a state of maturity, of poor quality with a bad odour. This perfume could not be used immediately and it had to be kept until the smell improved.

The second method, perceived as producing higher quality perfume, involved gathering the substance secreted naturally by the deer's body. According to Ibn Aknin, when the perfume matures it accumulates in the deer's navel. The maturation stage causes the deer to feel pain and itchiness, whereupon it scratches its belly on rocks warmed by the sun. The friction causes the deer pleasure and consequently the aromatic substance is secreted on the rocks (Compare to Nahmanides' description below, who also notes that scratching the gland occurs specifically on hot days). The hunters or gatherers of the perfume, who are familiar with the phenomenon, detect the fluid that dries over time on the rocks and gather it in their vessels.

Zoologically, secreting the perfume on rocks as a result of 'a need to scratch', as understood by the ancients, indicates the spreading of aromatic substances for purposes of scent marking and intraspecific communication. Many mammals have secretion glands in various parts of the body, such as in the area of the anus, the groin, the stomach and the front of the eye. These glands are usually located in a pocket and there are two types: glands that secrete an aromatic substance and glands that secrete an oily substance that slows down the evaporation of the aromatic substance.

Aromatic substances (pheromones) are spread by mammals on rocks, trees, bushes, etc., in this way conveying different messages to others of their species. In the oestrus period, mammals secrete special aromatic substances and the production of aromatic substances increases (Alexander 1986: 96-97; Matthews \& Knight 1963:103-108; Mendelssohn \& Yom-Tov 1990:17). Ibn Aknin's description of the phenomenon as characteristic of hot days specifically is associated with the oestrus and mating season that occurs in the hottest season. The ancients probably identified the fluids secreted on the rocks as high-quality perfume because, as stated, at this stage the aromatic substances are special and intense.

\section{Gathering musk in medieval Muslim sources - Ibn Aknin's sources}

From where did Ibn Aknin derive his knowledge on the behaviour of the deer, and on capturing and gathering musk? Ibn Aknin notes at the end of his interpretation that he took the information on gathering the perfume from testimonies of 'ancients' and that he is bringing their words as said. He does not state explicitly what were his sources and his words are probably taken from Muslim writings of nature that closely describe the phenomenon. 
Some of the first descriptions of musk deer and of how the perfume was produced are those of Al-Sirāfī, Abū Zāyd who lived in the beginning of the 10th century (Al-Sirāfi 1999:75-77), Al-Mas'ūdī ibn al-Ḥusayn who died in 956 (Al-Mas'ūdī 1962-1997:vol. I, 98) and Ibn Juljul ibn Ḥasān who I have mentioned before. Anya King has already spoken about the similarity between the descriptions of al-Sirāfī and al-Mas 'ūdi and raised the possibility that they had met in person and exchanged information about the musk deer (King 2017:168). Al-Mas 'ūdī's description was the source for many later descriptions of musk deer and it was utilized, amongst others, by the Andalusian, botanist and physician, Ibn al-Bayțār al-Mālaḳ̄ and by the Persian-Baghdadi physician and geographer Al-Qazwīnī, Zakarīyā ibn Muhammad (1203-1283) (Al-Qazwīnī 1967:vol. I, 383; Ibn alBayțār al-Mālaḳī 1874:vol. IV, 155-156).

In the next lines, we shall cite a paragraph from the words of al-Mas ' ūdī and compare them to the description of Ibn Aknin. Al-Mas' ūdī writes:

The land which has musk gazelles is in Tibet and China [...]. Tibetan musk is superior to Chinese musk for two reasons. First, the musk gazelle which is in the territory of Tibet has grazing lands of spikenard and various types of aromatic plants [...] The other respect is that the people of Tibet do not bother to remove the musk from the vesicle and they leave it as it is within it [...] The best and most fragrant musk is that which comes out from the gazelle after it has reached the end of its maturation [...] In Tibet and China they set up snares and nets for them and they trap them. Sometimes they shoot arrows at them and fell them. Then they cut the pods from them. The blood which is in the navel is raw and not matured and fresh and not ripened. It has a stench for its scent. They leave it for a time until that stinking, offensive odor has left it [...] The best musk is what matured in its vessel and ripened the navel [...] To be precise, natural forces push the matter of the blood to his navel. When the blood has matured and ripened within, it bothers the animal, and it causes him to scratch, so he seeks refuge at stones or rocks warmed by the heat of the sun and there rubs himself on them finding relief through that then it [=the navel] bursts forth and it [=the musk] flows upon those rocks as an abscess or boil bursts when whatever matter has collected in it successively has matured. The men of Tibet go out towards its grazing lands among those rocks and mountains to find the blood which has become dried on those stones and rocks [...] Then they take it and that is the best musk. (Al-Mas'ūdī 1962-1997:vol. I, 98; The English translation is according to King 2017:169-171)

There are many similarities between the descriptions of Ibn Aknin and Al-Mas 'ùdī. Both refer to the production of musk in Tibet and China and note the superiority of musk originating from Tibet because the deer there feed on aromatic plants. They both distinguish between capturing the deer and cutting off the bladder, which produces lowquality musk, and choice aromatic musk secreted from the body after the maturation stage. They both similarly describe the physiological process that occurs in the deer's body blood that matures in the navel annoys the deer and causes it to itch. ${ }^{3}$ They both note that rubbing against hot rocks leads to secretion of the pocket's contents and a sensation of relief from the itching. They both note that the natives gather the secreted substance from the rocks and stones and that it is considered very choice.

The similarity between the two descriptions indicates that Ibn Aknin probably derived his information from AlMas 'ūdī's book or from a later compilation based on it. Ibn Aknin understood the realistic descriptions in the writings of contemporary Muslim scholars as proof that the myrrh in the Song of Songs (5:1) is undoubtedly a choice perfume and that the manner in which it is gathered is compatible with the operation of ariya mentioned in the verse.

\section{Ariya - Gathering musk according to Naḥmanides}

The possibility that the operation of gathering musk is considered ariya is also mentioned in short in the biblical commentary of R. Moses Ben Naḥman (Nahmanides 11941270), one of the greatest Jewish sages who operated in Christian Spain in the middle ages. Nahmanides, a commentator on the Bible and Talmud, thinker, kabbalist and physician, was born in Girona in northeast Spain. He completed his biblical commentary whilst living in Spain, several years before traveling to live in Eretz Israel in 1267 (On Naḥmanides, see Funkenstein 1980:35-59, 1991:164-168; Halbertal 2006; Licht 1983:60-68).

Nahmanides, in his interpretation of the ingredients of the holy anointing oil (Exodus 30:23), identified the biblical myrrh with Commiphora abyssinica. He argued that myrrh is not musk, as in rabbinical literature mor (myrrh) and musk (musk) appear as distinct terms. The midrash identifies mor as 'inmarinon', that is, the resin of the myrrh tree. ${ }^{4}$ In contrast, musk is a different term designating the perfume produced from musk deer (Jerusalem Talmud 1523: Berakhot 6:6, 10d; Babylonian Talmud 1882:Berakhot 43a). Moreover, Midresheiaggadah notes that myrrh is a perfume that becomes fragrant only once it is burned as incense (Song of Songs Rabbah 1885-1887:12a). This feature is typical only of the myrrh tree, whilst musk is fragrant even when not burned (Nahmanides 1959:vol. I, 496; On the identification of the myrrh in the Bible, see Felix 1997:97).

Although Nahmanides rejected the identification of the Biblical myrrh with musk, he raised the possibility that the unique manner of gathering musk is an operation that involves harvesting. In response to Ibn Ezra, who noted the difficulty of ascribing harvesting to an animal-based perfume, he wrote (Nahmanides 1959):

Perhaps [the scriptures] say 'I have gathered my myrrh' because this is blood that solidified within the belly of an animal that resembles a gazelle, which is common in the land of India, and when it treads among the bushes in days of great heat it scratches

Juljul doesn't mention the phenomenon of itching and the deer's rubbing against the rocks.

4.According to R. Benjamin Ben Emanuel Musafia (Spain and Netherlands 1606-1675), 'oinomyrines' (oiveupívns) is wine mixed with myrrh and spices (see Musafia 1955:vol. I, 150). 
that swelling [=swollen gland], and the blood emerges in a solidified form and it is gathered [by people] from the pasture. (vol. I, p. 496)

As we saw above, Ibn Ezra contends that musk is produced in the 'throat of the gazelle', but he does not state explicitly that this is blood. Nahmanides, in contrast, explains that musk perfume is blood that accumulates in a gland in the belly of the 'gazelle' that is common in India. He also relates that on hot days the deer scratches the gland, whereupon the blood is excreted. At this time, those who gather the perfume go out into the fields and harvest it, which is why the operation is called ariya. Nahmanides states that 'the blood emerges in a solidified form', indicating that it dries up from the heat and becomes solid, which explains the phrase tzror hamor [a sachet of myrrh] in Song of Songs 1:13.

From where did Nahmanides derive his knowledge on the behaviour of the deer, and on capturing and gathering musk? He does not refer to his sources; however, part of his concise interpretation is based on widespread medieval geographical, zoological and physiological conceptions regarding the identity and habitat of the musk deer as well as regarding the essence and origins of the perfume produced from its body. The portrayal of the musk deer as a gazelle or an animal that resembles a gazelle that originates from India, and the perfume produced from it as 'blood', appears in the compilations of Muslim scholars in Spain (On the possibility that Nahmanides derived his knowledge from Arabic sources, I shall discuss below).

An example of this is the short description by Andalusian physician Abu Dawud Sulayman ibn Hassan IbnJuljul (c. 944 Córdoba-c. 994), who provides information about musk when listing its medical qualities. He writes:

misk - an Indian drug and it is a gland full of musk that falls from the legs of a beast the size of deer [gazelle]. There are in their legs bulges that never stop growing and filling up with the blood of this animal, and when they filled up they fall off the animal, and the musk is inside, and some say that these bulges are in the intestines [correction: navel] of this animal. (The English translation of this passage is according to Amar, Lev \& Serri 2014:549)

India is the habitat of the Himalayan musk deer (Moschus leucogaster) (Singh et al. 2019:4-18). The geographical meaning of the term 'India' as utilized in rabbinical language may be wider than the country itself, encompassing the entire Far East. In any case, India (in addition to Tibet, China, and Turkey) was one of the centres from which musk was imported to Western Europe, including Spain (Akasoy \& Yoeli-Tlalim 2007:217-240).

With regard to the nature and origins of musk, according to one approach held also by Nahmanides, this is blood. Assumedly, musk was mistaken for blood because of its redbrown colour; however, we must stress that this secretion is unrelated to blood (see below). Other Jewish sages in Christian Spain described the aromatic product as 'sweat', that is, an animal secretion (Rabenu Jonah 1981:43a).
Another point discussed in Jewish medieval compilations is where in the deer's body is the perfume produced. Some claimed that the blood accumulates once a year in the deer's navel as a result of excess blood in its body (King 2017:162-164, 207-213). According to another tradition common amongst Jewish scholars in Christian Spain, such as in Rabenu Jonah who was a relative of Nahmanides, the perfume is produced in the deer's neck (Asher ben Yehhiel 1981:28b; Rabenu Jonah 1981:43a), where some noted that it develops in a special pocket (Abudarham1878:92a).

The tradition concerning the origins of the perfume in the deer's 'belly' is closest to the truth, as the musk gland is located under the deer's belly near the genitals. The lack of clarity regarding the origins of the musk in the deer's body undoubtedly stemmed from the fact that the musk deer does not live in the Near East and the animal and its behaviour could not be observed directly.

\section{Discussion and conclusions}

Musk is not mentioned in the Bible and no historical source indicates that it was known in Eretz Israel at that time. In the Talmudic literature, it is mentioned in the context of the blessing recited over its fragrance, but we have no rabbinical source that identifies it with the biblical myrrh. In fact, only in the Middle Ages did biblical commentators begin to identify it with the biblical myrrh, and this appears to be associated with the fact that at this time musk became lucrative and was considered prestigious. It is to be assumed that the sages were influenced by the contemporary world of perfumes and were inclined to identify important perfumes with which they were familiar with superior perfumes mentioned in the Bible or ritual substances utilized in the temple.

The medieval identification of musk with the biblical myrrh or the myrrh mentioned in the rabbinical literature (Talmud and midrash literature) arouses two main questions - its incompatibility with the descriptions of the myrrh and its qualities. The incongruence discussed in the current article is that in the Song of Songs it is mentioned as a substance that is described as being gathered, a quality fit for a plant-based substance. Ibn Aknin, who supported the identification of biblical myrrh with musk, finds proof of its gathering in realistic descriptions of the musk industry in its lands of origin in the Far East. He contends that harvesting the perfume does not refer to capturing the deer and cutting off the pocket of perfume, rather to gathering the perfume that the deer spreads on the rocks naturally, which is a higher quality product.

The interpretations of Ibn Aknin and Nahmanides are an example of medieval biblical interpretations based on later circumstances that were familiar to the commentator. As we have seen, the large geographical distance between the locations in which musk was produced in the Far East and the region of Europe and the Mediterranean Basin created information incongruities regarding the musk deer and the 
perfume produced from it. This fact explains the diverse opinions regarding the origin of the perfume in the body of the deer - in its belly, navel or neck.

Nahmmanides and Ibn Aknin were exposed to contemporary information and traditions with regard to how musk was gathered. However, there are many differences between them. They were from a completely different time and place and they were influenced by a different cultural environment. As we have seen Ibn Aknin reports that he took his information from the work of Arab scholars. Ibn Aknin spent most of his life in North Africa, presumably Fez, Morocco. He lived in Arab lands and clearly was well schooled in all areas of knowledge available there. He knew the Arabic language, read Arabic literature and was influenced by Arab scholars. As Abraham Solomon Halkin (1971) writes:

Aknin is typical of a group of intellectuals in the Jewish community under Islam that was impressed with the learning and doctrines of Greek and Hindu origin cultivated by Muslim intellectuals. However, he saw no conflict between his religious and secular learning. (p. 501)

Ibn Aknin read in Muslims books on the way of gathering the musk, and it is possible that this is the reason why his description is much lengthier and more detailed.

In the case of Nahmanides, we cannot ascertain the source of his knowledge. As known from other contexts, Nahmanides derived information for his commentaries and philosophy from several sources - personal experience and observation of his close environment (Nahmanidas 1959:vol. II, 96), the books of non-Jewish sages (Nahmanidas 1959:vol. II, 427-428) and conversations he conducted with contemporary non-Jewish scholars, for instance, diviners (Nahmanides 1963:vol. I, 146). ${ }^{5}$

Is it possible that Nahmanides read about the musk deer and the way of gathering the perfume from Arabic sources? In fact, Nahmanides was active almost his entire life in Christian Spain. Generally, in this region, Latin was the language of culture and religion, and the Castilian was the language of the street. On the other hand, in Muslim Spain, Arabic was the language of culture and religion, but also spoken vernacular (Lupovitch 2010:97). It is far from clear whether Nahmanides could read Arabic and this issue has been debated by various scholars (The question whether Nahmmanides could read Arabic has been debated by various scholars; see Unah 1976:10; Yahalom 2003:3; Yoshpe 1987:67-93). Moreover, he also definitely did not have access to the rich literature written in Arabic that Ibn Aknin had.

In Middle Ages, zoological information could be found in the European bestiaries (bestiarumvocabulum), a genre of animal books encompassing descriptions and explanations

5.Ezra Zion Melamed stated that the grounds for Nahmanides' exegesis is the knowledge he acquired in various ways: personal experience, life circumstances,
studies, and encounters with rabbis and scholars (see Melamed 1978:954-957; studies, and encounters
Shemesh 2019:93-119).

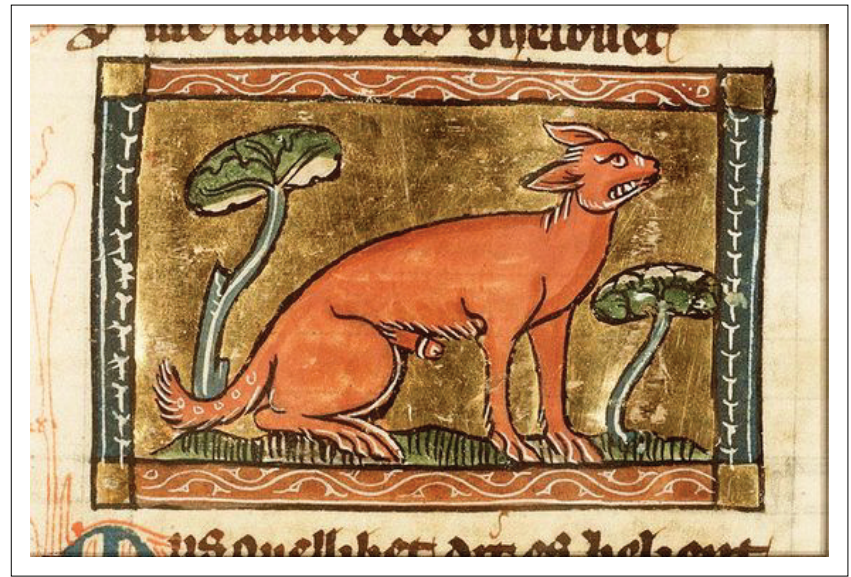

Source: Photo courtesy of Van Maerlant, J., n.d., 'Musquelibet (musk deer)', in Der naturen bloeme, 64r, Koninklijke Bibliotheek (Nederland), (KB KA 16), viewed 18 January 2021, from hloeme, 64r, Koninklijke Bibliotheek (Nederland), (KB KA 16), viewed 18 January 2021, from 65.99443315755708/Ing/56.309764981269836

FIGURE 1: Musquelibet (musk deer). The illustrator emphasized the genitalia and the perfume bladder.

on a variety of animals (some real some legendary), together with illustrations and morals related to each animal (Baxter 1998:83). These books were popular in medieval England and France and were also found in Spain (On Latin, English and French Bestiaries manuscripts, see McCulloch 1960:1-25; Stewart 2012:93-110; White 1960; On Bestiaries in medieval Spain, see Baldwin 1982, 2013: 164-165). The musk deer is described in this literature, but it seems in a limited manner (see Figure 1). In any case, there is no evidence that Nahmanides used this literature.

\section{Acknowledgements Competing interests}

The author has declared that no competing interest exists.

\section{Author's contributions}

A.O.S. is the sole author of this research article.

\section{Ethical consideration}

This article followed all ethical standards for a research without direct contact with human or animal subjects.

\section{Funding information}

This research received no specific grant from any funding agency in the public, commercial, or not-for-profit sectors

\section{Data availability statement}

Data sharing is not applicable to this article as no new data were created or analysed in this study.

\section{Disclaimer}

The views and opinions expressed in this article are those of the author and do not necessarily reflect the official policy or position of any affiliated agency of the author. 


\section{References}

Abudarham, D., 1878, Abudarham ha-Shalem, Nathan Shriptgisser, Warsaw.

Akasoy, A. \& Yoeli-Tlalim, R., 2007, 'Along the musk routes: Exchanges between Tibet and the Islamic world', Asian Medicine 3(2), 217-240. https://doi.org/ 10.1163/157342008X307857

Al-Mas'ūdī \& Al-Mas'ūdī ibn al-Husayn, 1962-1997, KitābMurūj al-dhahabwama'ādin al-jawāhir (=Les Prairies d'Or), B. De Meynard \& P. De Courteille (eds.), Impr. Impériale, Paris.

Al-Qazwīnī \& Zakarīyā ibn Muhammad, 1967, 'Aja'ib al-makhluqat, in Kosmographie, vol. 1, Die Wunder der Schöpfung, F. Wüstenfeld (ed), Dieterich, Göttingen, 1849 (reprint: Kosmographie Die Wunder der Schopfung / Zakarija Ben Muhammad Ben Mahmud el-Cazwini, aus den Handschriftender Bibliothekenzu Berlin, Gotha, Ben Mahmud el-Cazwini, aus den Handschriftender Bibliothekenzu Berlin, Gotha, Dresden und
Wiesbaden).

Al-Sirāfi \& Abū Zāyd., 1999, Rihlah, Abdallāh al-Habashi (ed.), Manshūrāt al-Majma' al-Thaqāfi, Abu Dhabi.

Albeck, H., 1952, Mishnah, Mossad Biyalik and Dvir, Jerusalem.

Alexander, R. M., 1986, The Collins Encyclopedia of Animals Biology, HarperCollins Publishers, London.

Amar, Z. \& Lev, E., 2017, Arabian drugs in medieval Mediterranean medicine, Edinburgh University Press, Edinburgh.

Amar, Z., 2002, The book of incense, Eretz, Tel Aviv [Heb.].

Amar, Z., Lev, E. \& Serri, Y., 2014, 'On Ibn Juljul and the meaning and importance of the list of medicinal substances not mentioned by dioscorides', Journal of the Royal Asiatic Society 24(4), 529-555. https://doi.org/10.1017/S1356186314000029

Asher ben Yehhiel, R., 1981, Commentary of Rabenu Asher on Berakhot Tractate, Shas Vilna, Romm Press, Vilna 1880 (rep. Talman, Ramat Gan, 1981).

Babylonian Talmud, 1882, The Widow and Brothers Romm, Vilna.

Baldwin, S. W., 1982, The Medieval Castilian Bestiary. University of Exeter, Exeter, Devon.

Baldwin, S. W., 2013, 'Bestiary', in Gerli, E. M., Medieval Iberia: An Encyclopedia, Routledge, London and New York.

Baxter, R., 1998, Bestiaries and Their Users in the Middle Ages, Sutton publication, Stroud.

Blau, J., 2006, Dictionary of mediaeval Judaeo-Arabic Texts, Y. Kara (ed.), Academy of the Hebrew Language, Jerusalem [Heb.].

Felix, Y., 1997, Trees: Aromatic, ornamental and of the forest, in the Bible and Rabbinic literature, Reuven Mass, Jerusalem [Heb.].

Funkenstein, A., 1980, 'Naḥmanides': Typological reading of history', Zion 45(1), 35-59 [Heb.].

Funkenstein, A., 1991, Historical images and historical consciousness in Judaism and its cultural surroundings, Am Oved, Tel Aviv [Heb.].

Goitein, S.D. \& Friedman, M.A., 2013, India book IV/B: Halfon the traveling merchan scholar-Cairo Geniza documents, Keren ha-rav David Moshehve-Amalyah Rozen, Jerusalem [Heb.].

Goitein, S.D., 1973, Letters of medieval Jewish traders, Princeton University Press, Princeton, NJ.

Goitein, S.D., 1983, A mediterranean society: The Jewish communities of the Arab world as portrayed in the documents of the Cairo Geniza, IV, University of California Press, Los Angeles, CA.

Green, M.J.B., 1987, 'Some ecological aspects of a Himalayan population of musk deer', in C.M. Wemmer (ed.), Biology and management of the Cervidae, pp. 307-319, Smithsonian Institution Press, Washington, DC.

Halbertal, M., 2006, By way of truth: Nahmanides and the creation of tradition Shalom Hartman Institute, Jerusalem [Heb.].

Halkin, A.S., 1944, 'Classical and Arabic material in Ibn Joseph Aknin's "hygiene of the soul"', American Academy for Research XIV, 27-37. https://doi.org/10.2307/ 3622106

Halkin, A.S., 1963, 'On the image of Joseph ben Judah ibn Aknin', in S. Lieberman (ed.), Harry Austryn Wolfson jubilee volume: On the occasion of his seventy-fifth birthday, pp. 93-111, American Academy for Jewish Research, Jerusalem.

Halkin, A.S., 1964, Inkishāf al-asrarwatuhūr alanwār (=The divulgence of mysteries and the appearance of lights), Mekitze Nirdamim, Jerusalem.

Halkin, A.S., 1971, 'Aknin, Joseph Ben Judah Ben Jacob Ibn', in C. Roth (ed.) Encyclopedia Judaica, vol. II, p. 501, Keter Publishing House and Macmillan Company, Jerusalem.

Ibn al-Bayțār al-Mālakīi, 1874, Kitāb al-Jāmi' li-Mufradāt al-Adwiyawa-l-Aghdhiya, 4 vols., Al-Mațba'ä̈ al-'Āmirä̈, Bulaq (repr. Baghdad, n. d).

Jerusalem Talmud, 1523, Daniel Bomberg, Venice.

Karo, J., 2002, Kesef Mishneh on Mishneh Torah of Maimonides, S. Frankel, Jerusalem.
King, A., 2011, 'Tibetan musk and medieval Arab perfumery', in A. Akasoy, C. Burnett \& R. Yoeli-Tlalim (eds.), Islam and Tibet: Interactions along the musk routes, pp. 145-162, Ashgate, Farnham.

King, A.H., 2017, Scent from the garden of paradise: Musk and the medieval Islamic world, Brill, Leiden.

Licht, Y.S., 1983, 'Ramban', in M. Greenberg (ed.), Jewish Bible exegesis - Introductory chapters, pp. 60-68, Mossad Bialik, Jerusalem. [Heb].

Löw, I., 1924, Die Flora der Juden, R. Löwit, Vienna.

Lupovitch, H. N., 2010, Jews and Judaism in world history, Routledge, London.

Maimonides, M., 1970, Mishnah with the commentary of Maimonides, First Press, Napoli 1492, A. M. Haberman edition, Sifriyat Makor, Jerusalem.

Maimonides, M., 2002, Mishneh Torah, edited by S. Frankel, Hotza'at Shabse Franke LTD, Jerusalem.

Matthews, H.L. \& Knight, M., 1963, The senses of animals, Museum Press Limited, London.

McCulloch, F., 1960, Medieval Latin and French Bestiaries, University of North Carolina Press, Chapel Hill.

Melamed, E.Z., 1978, Biblical commentaries: Their methods and approaches, Magnes Press, Hebrew University, Jerusalem [Heb].

Mendelssohn, H. \& Yom-Tov, Y., 1990, 'Scent glands', in A. Alon (ed.), Plants and animals of the land of Israel: An illustrated encyclopedia, VII: Mammals, P. 17, Ministry of Defense, Tel Aviv [Heb.].

Musafia, B.E., 1955, 'Musf ha-Arukh', in R. Nathan me-Romi, (ed.), Sefer ha-Arukh, p. 150, Hanoch Yehuda Kohut (edn.), Pardes, New York, NY.

Nahmanides, M.B.N., 1959, The commentary of Ramban on the Tora, Haim Dov Chavel (edn.), Mossad ha-Rav Kook, Jerusalem.

Nahmanides, M.B.N., 1963, 'Torat ha-Shem Temima', in H. Dov Chavel (ed.), Writings of Nahmanides, p. 146, Mossad ha-Rav Kook, Jerusalem.

Naḥmanides, M.N., 1955, 'Iggeret ha-Kodesh [=The holy letter]', in Moshe Ershler (ed.), in ChiddusheiRamban[=Ramban's glosses], p. 329, Machon ha-Talmud ha-Israeli ha-Shalem, Jerusalem.

Nowak, R.M., 1991, Walker's mammals of the world, The Johns Hopkins University Press, Baltimore, MD.

Perry, M.E., 2012, 'Morisco stories and the complexities of resistance and assimilation' in K. Ingram (ed.), The conversos and moriscos in late medieval Spain and beyond vol. II: The morisco issue, pp. 161-186, Brill, Leiden.

Rabenu Jonah, Girundi, 1981, 'Commentary of Rabenu Jonah Girundi on the Talmud', in Shas Vilna, Romm Press, Vilna 1880 (rep. Talman, Ramat Gan, 1981).

Ravad, A.D., 2002, Criticism of Rabbi Abraham ben David to Mishneh Torah of Maimonides, S. Frankel, Jerusalem.

Sa'adya Gaon, 1984, Commentary of R. Sa'adya Gaon on the Torah, Joseph Kapach (ed.), Mossad ha-Rav Kuk, Jerusalem.

Sela, S. \& Freudenthal, G., 2006, 'Abraham Ibn Ezra's scholarly writings: A chronologica listing', Aleph 6, 13-55. https://doi.org/10.2979/ALE.2006--.6.13

Shapira, N., 1959a, 'On the scent materials derived from animals in the Hebrew sources', ha-Rofeh ha-lvri 32(1), 153-161 [Heb.].

Shapira, N., 1959b, 'The musk in Hebrew sources', Leshonenu 23(3), 185-187 [Heb.].

Shemesh, A.O., 2019, 'Two medieval necromantic practices: Maimonides versus Nahmanides and R. Joseph Albo concerning Ob and Yidoni', Review of Rabbinic Judiaism 22(1), 93-119. https://doi.org/10.1163/15700704-12341352

Simon, U., 2013, The ear discerns words: Studies in Ibn Ezra's exegetical methodology, Bar Ilan University Press, Ramat Gan. [Heb.].

Singh, P.B., Saud, P., Cram, D., Mainali, K., Thapa, A., Chhetri, N.B. et al., 2019 'Ecological correlates of Himalayan musk deer Moschus leucogaster', Ecology and Evolution 9(1), 4-18. https://doi.org/10.1002/ece3.4435

Song of Songs Rabbah, 1885-1887, The Widow and Brothers Romm, Vilna.

Stewart, P., 2012, The Mediaeval Bestiary and its Textual Tradition (Volume 1: Text). Doctoral thesis, University of St Andrews, Scotland.

Unah, I., 1976, R. Moses ben Nahman -The Ramban, Kiryat Sefer, Jerusalem.

Van Maerlant, J., n.d., 'Musquelibet (musk deer)', in Der naturen bloeme, 64r, Koninklijke Bibliotheek (Nederland), (KB KA 16), viewed 18 January 2021, from https://galerij.kb.nl/kb.html\#/nl/dernaturenbloeme/page/65/zoom/3/lat/65.99443315755708/lng/56.309764981269836

Veizer, A., 1976, Abraham Ibn Ezra commentary on the Torah, Mosad ha-Rav Kook, Jerusalem [Heb.].

Watt, G.1966, The commercial products of India, John Murray, London, 1908 (reprint Delhi).

White, T. H., 1960, The Bestiary, Capricorn Books, New York.

Yahalom, S., 2003, The Halakhic Thought of Nahmanides According to his Provencal Sources, Doctoral thesis, Bar-llan University Ramat-Gan.

Yoshpe, R., 1987. 'Nahmanides and the Arabic', Tarbitz 57, 67-93. 